\title{
Intertidal seagrass beds (Zostera noltii) as spawning grounds for transient fishes in the Wadden Sea
}

\author{
Patrick Polte*, Harald Asmus \\ Alfred Wegener Institute for Polar and Marine Research, Wadden Sea Station Sylt, Hafenstrasse 43, 25992 List, Germany
}

\begin{abstract}
Since the major seagrass loss in the 1930s, the former extensive seagrass beds (Zostera marina) in the Wadden Sea (North Sea) are now exclusively limited to the intertidal area and are dominated by $Z$. noltii. We hypothesised that intertidal seagrass beds are important spawning areas for common North Sea fishes. To study the role of $Z$. noltii beds as a spawning ground in general, different investigative approaches had to be used with respect to the biology of fish species and the timing of field investigation within the spawning processes. In situ spawning experiments combined with comparisons of fish activity and abundance on vegetated and non-vegetated tidal flats indicated the importance of intertidal seagrass beds as spawning grounds for the garfish Belone belone. The tidal migration of $B$. belone was found to be specifically directed to intertidal $Z$. noltii beds for spawning; furthermore, the seagrass plants were found to be significantly more effective in adhering eggs than alternative plant substrates such as the brown algae Fucus vesiculosus. Besides being found in $Z$. noltii beds, eggs of herring Clupea harengus were also found attached to F. vesiculosus associated with man-made constructions for coastal protection located in the upper intertidal zone. However, comparisons of egg numbers in relation to plant biomass $\mathrm{m}^{-2}$ revealed that densities of herring spawn were about 20 times higher in seagrass beds than in brown algal patches. Disguised nests of the three-spined stickleback Gasterosteus aculeatus could only sporadically be observed within the intertidal seagrasses canopies. Since over $50 \%$ of the female individuals of G. aculeatus captured within $Z$. noltii beds carried ripe ovaries, we proposed that intertidal seagrasses are suitable spawning grounds for small species such as G. aculeatus, which have distinct parental care behaviour.
\end{abstract}

KEY WORDS: Intertidal seagrass - Zostera noltii - Spawning - Fishes $\cdot$ Belone belone $\cdot$ Clupea harengus $\cdot$ Gasterosteus aculeatus $\cdot$ Wadden Sea $\cdot$ North Sea

\section{INTRODUCTION}

The variety of ecological functions that subtidal seagrass beds fulfil for fishes worldwide is well documented (e.g. Orth et al. 1984, Connolly 1994, Edgar \& Shaw 1995, Scott et al. 2000, Beck et al. 2001, Minello et al. 2003), whereas intertidal seagrass systems have attracted less attention in this respect, especially in northern latitudes. In general, the high structural complexity of seagrass beds is considered to provide shelter from predation (Nelson \& Bonsdorff 1990, Mattila 1992, Hindell et al. 2001), support larval settlement (Short \& Short 1984, Grizzle et al. 1996, Boström \&
Bonsdorff 2000, Moksnes 2002) and reduce the effects of currents and waves (Fonseca et al. 1982, Gambi et al. 1990, Fonseca \& Calahan 1992, Koch \& Gust 1999). Losses of seagrass biotopes are often followed by a reduction in species diversity and abundances within invertebrate and fish communities (Thrush et al. 2001, Hughes et al. 2002, Wyda et al. 2002, Vanderklift \& Jacoby 2003).

In the North Sea area, a decline in fish diversity is rarely interpreted as a consequence of current habitat loss, but rather as a consequence of anthropogenically induced effects such as over-fishing and chemical pollution (Lakke 1985, Jennings \& Kaiser 1998, Philip- 
part 1998, Groehsler \& Zimmermann 2001, Christensen et al. 2003, Elliott 2003). However, after the loss of the entire subtidal seagrass stocks in the Wadden Sea during the 'wasting disease' in the 1930s, Wohlenberg (1935) documented that migratory fish species such as the herring Clupea harengus had lost important spawning grounds, which was subsequently reflected in the decrease of local herring stocks. Similar observations from 'wasting disease' events in the White Sea during the 1960s emphasised the negative effects of seagrass losses on herring populations (Gemp \& Bryzova 1968, Goscheva 1970, Wechov 1987, E. Rachor pers. comm.).

In the Wadden Sea, the processes that led to the collapse of subtidal Zostera marina stocks in the 1930s and the reasons for the failure of their re-establishment to this day are still discussed controversially and are objects of intensive research. Today, in the Wadden Sea, seagrass beds are limited exclusively to the intertidal area where they occupy about $51 \mathrm{~km}^{2}$ in total (Reise 2003). Despite a general decline in Z. noltii stocks during the past 3 decades (den Hartog \& Polderman 1975, Michaelis 1987), they have remained relatively stable in the northern part of the Wadden Sea (Reise 2003). Here, Z. noltii beds are regularly exposed to the air during the semi-diurnal tidal cycle. For fishes they represent temporarily available habitats during high tides and are subject to large fluctuations in environmental conditions over a $24 \mathrm{~h}$ period. The question arises as to whether or not intertidal seagrass beds have any ecological function as spawning grounds similar to that assumed for subtidal beds.

The aims of this study were to asses the role of intertidal Zostera noltii beds as spawning areas for 3 common fish species that exhibit different reproduction strategies: (1) the garfish Belone belone, which releases single, relatively large eggs $(\varnothing 3 \mathrm{~mm})$ covered by numerous filaments, which facilitate attachment to the substrate (Duncker et al. 1929, Rosenthal \& Fonds 1973, Dorman 1991), (2) the herring Clupea harengus, which attaches aggregations of up to several thousand dermersal eggs to the substrate (Messieh et al. 1985, Hoshikawa et al. 2001), and (3) the three-spined stickleback Gasterosteus aculeatus, which builds nests from plant material where aggregations of eggs are under intensive parental care by the males (Reebs et al. 1984, Lachance \& FitzGerald 1992, Rowland et. al. 2002).
By means of experimental manipulation of spawning substrates combined with observation of fish activity and quantitative sampling methods, this study focused on the role of the remaining intertidal seagrass stocks in the Wadden Sea for fish reproduction. As there is no information available about this subject, it was hypothesized that (1) intertidal Zostera noltii beds are relevant spawning ground for common, migratory fish species, and (2) the significance of $Z$. noltii beds as a spawning substrate exceeds that of alternative macroalgae.

\section{MATERIALS AND METHODS}

Study sites. Studies were conducted on the east coast of the island of Sylt in the northern Wadden Sea (North Sea) (Fig. 1). The tidal flats under investigation were situated within a shallow tidal basin formed by the mainland and the islands of Sylt (Germany) and Rømø (Denmark). Along the tidal watersheds, the Sylt-Rømø Bight is nearly closed by causeways connecting the islands with the mainland. A single inlet joins the Bight to the open North Sea. Tides are semidiurnal with an average amplitude of about $2 \mathrm{~m}$, and salinity ranges seasonally from 28 in winter to 32 in summer. During our study, the mean water temperature throughout the vegetation period of Zostera noltii (May to September) was about $18^{\circ} \mathrm{C}$, and water depth in investigated tidal areas ranged from 0.7 to $1 \mathrm{~m}$ at high tide.

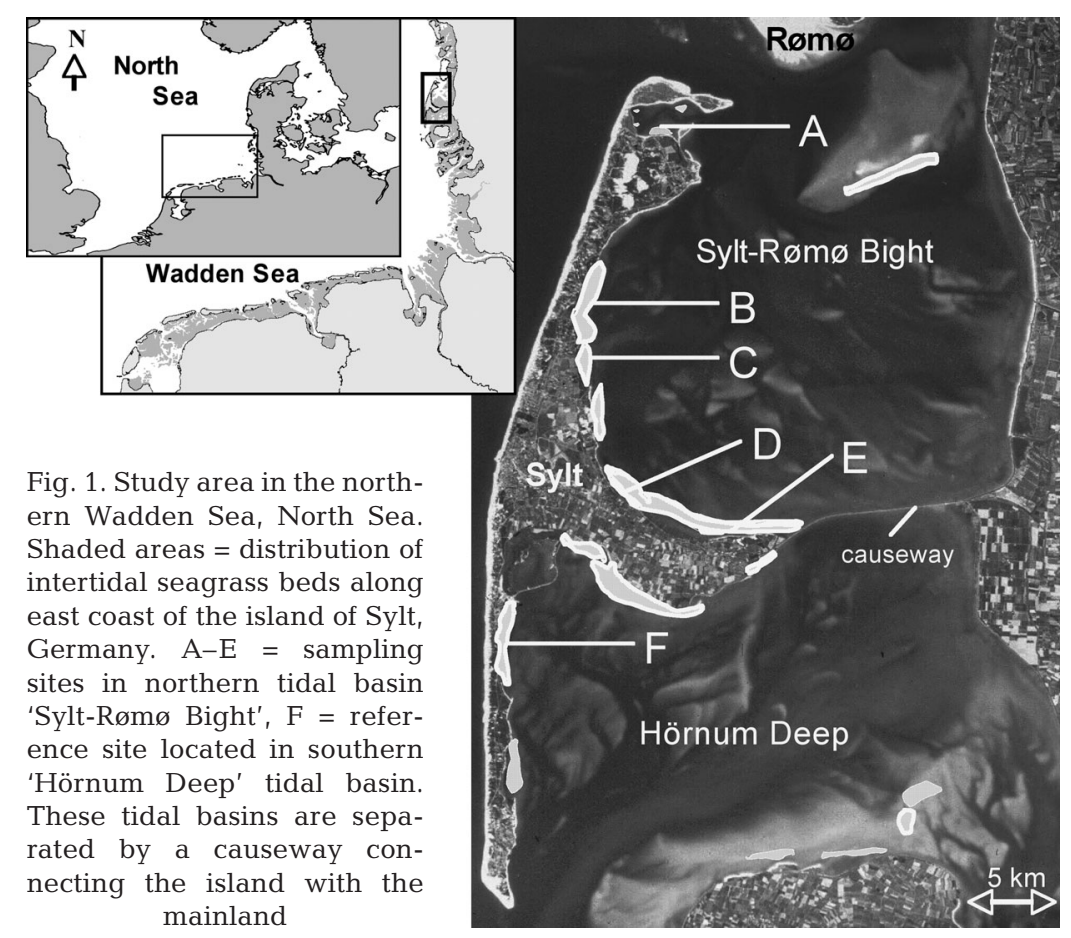


In the Sylt-Rømø Bight bare sand flats dominate the intertidal area. Mussel beds (Mytilus edulis) occupy $0.3 \%$ of the intertidal zone, and are mostly covered by the brown algae Fucus vesiculosus (Gätje \& Reise 1998). Mussel beds are located at the lower range of the intertidal zone and are periodically exposed for 1 to $3 \mathrm{~h}$ during low tide (Asmus 1987, Buschbaum \& Saier 2001). Seagrass beds are dominated by Zostera noltii and cover about $12 \%$ of tidal flats (Gätje \& Reise 1998). Depending on their exposure to tidal currents, shoot densities vary from 2000 to 5000 shoots $\mathrm{m}^{-2}$ during August and September (Schanz \& Asmus 2003). These dense canopies usually retain a 5 to $10 \mathrm{~cm}$ deep layer of residual water between the plants during the low tide period. Seagrass beds are located close to the mean high tide mark and are exposed to air for periods of 4 to $6 \mathrm{~h}$ (Schanz et al. 2002). Experiments and sampling of fishes were carried out in a semi-exposed seagrass bed and on adjacent sand flats located within a distance of $1.5 \mathrm{~km}$ (Fig. 1, Site B). In order to map spawning of Belone belone within the Sylt-Rømø Bight, 5 different seagrass sites were sampled during June 2003 (Fig. 1, Sites A, B, C, D, E). One reference site was located outside the Sylt-Rømø Bight on the southern side of the causeway separating the intertidal system (Fig. 1, Site F).

Belone belone: Comparison of activity in different habitats. The pelagic garfish $B$. belone is highly mobile and thus extremely difficult to capture quantitatively by most current sampling techniques. B. belone shows a special behaviour when swimming close to the surface: it tends to overcome barriers by jumping. We exploited this behaviour to develop a method to compare activity among vegetated and adjacent nonvegetated areas that were located at the same tidal level and thus exposed for the same period of time. This method is termed 'jumping activity comparison' (JUMP). During the spawning season from early May to late July 2002, a $20 \mathrm{~m}$ long rope $(\varnothing 0.8 \mathrm{~cm}$ synthetic fibre) was loosely fixed on the water surface, and fish jumping over the floating rope were simultaneously counted in waters over bare sand and seagrass beds for a period of $30 \mathrm{~min}, 1 \mathrm{~h}$ before high tide (Fig. 1, Site B). Fish movement was measured on directly neighbouring vegetated and non-vegetated tidal flats located at an identical tidal level, in order to identify patterns of tidal migration. The method allowed a relative index of fish activity because sampling took place at the same time during the tidal cycle. Data were subsequently pooled over a period of $19 \mathrm{~d}$.

The JUMP method was also used to estimate the occurrence of garfishes at different intertidal seagrass sites during the main spawning period in June 2003. Five sampling sites were located within the Sylt-Rømø
Bight, and 1 reference site was located in the southern 'Hörnum Deep' tidal basin (Fig. 1). Over 1 mo, most of the sites were sampled once at the same time of day and point of tide respectively. Sampling was started at Site B (Fig. 1) and was repeated there at the end of the study period to determine possible effects on garfish occurrence caused by the intervening spawning period.

Belone belone: In situ spawning experiments. To test the specific role of seagrass plants for spawning $B$. belone, different structures were offered to the fishes at Site B (Fig. 1) as alternative spawning substrates during June 2002. The dominant brown algae Fucus vesiculosus was attached to PVC mats of $0.5 \mathrm{~m}^{2}$ area $\left(250 \mathrm{~g}\right.$ algal fresh weight $\left.\times 0.5 \mathrm{~m}^{-2}\right)$. Other mats were covered with bast fibres $\left(50 \mathrm{~g} \times 0.5 \mathrm{~m}^{-2}\right)$ as an artificial substrate, to assess whether the type of structure affects the attachment of fish eggs. Six replicates of each structure were placed in a Zostera noltii bed and on an adjacent sand flat bare of vegetation. As a control, we estimated egg abundance by randomly placing a metal frame of $0.5 \mathrm{~m}^{2}$ area on vegetated and non-vegetated tidal flats (6 replicates). Because of possible spawning peaks, mats and controls were examined for $B$. belone eggs on 4 occasions from the beginning of June to the middle of July. The eggs found in the investigation areas were removed to prevent accumulation from different spawning events.

Previous observations showed that Belone belone eggs attached to green algae (Enteromorpha spp., Chaetomorpha spp.) when algae occurred within seagrass beds during the spawning period.

We hypothesised that seagrass affects egg survival even when eggs are attached to different substrates, because the seagrass environment reduces desiccation at low tide. To determine the passive impact of seagrass cover on egg mortality, clumps of Enteromorpha spp. ( 150 g fresh weight) with Belone belone eggs attached were collected from the seagrass bed. Eggs on each algal clump were counted and clumps were fixed in the seagrass bed $(n=9$, mean egg number clump $^{-1}=6.4 \pm 0.3 \mathrm{SE}$ ) and on adjacent sand flats $(n=10$, mean egg number per clump $=5.1 \pm 0.2 \mathrm{SE}$ ). After $5 \mathrm{~d}$ the algal clumps were examined for numbers of eggs remaining as well as egg survival, based on analyses of yolk colour and on the condition of the eggshell (hatching of larvae causes a characteristic injury to the eggshell).

Abundances of Belone belone and Gasterosteus aculeatus. To estimate the abundance of spawning fishes in the intertidal zone, 2 beach seine hauls $\mathrm{mo}^{-1}$ from April to July 2003 were conducted. Two replicate samples were each taken in a Zostera noltii bed and on an adjacent sand flat at Site B (Fig. 1) on consecutive days, $1 \mathrm{~h}$ before high tide to $1 \mathrm{~h}$ afterwards. 
The beach seine consisted of a $2 \mathrm{~m}$ long bag of $4 \mathrm{~mm}$ mesh size attached to two $10 \mathrm{~m}$ long wings, $1.5 \mathrm{~m}$ in height with a $10 \mathrm{~mm}$ mesh size. The seine was hauled over a distance of $60 \mathrm{~m}$ with a mouth opening of $15 \mathrm{~m}$, sampling an area of $900 \mathrm{~m}^{2}$. The fishes caught were preserved by freezing. Quantitative data for species found were pooled over the sampling period, and abundances on vegetated and nonvegetated tidal flats were calculated and compared. For G. aculeatus a random sample of 99 females was tested concerning the percentage of egg carrying females. A second sample of 84 male sticklebacks was analysed for the percentage of individuals showing breeding colours.

Clupea harengus: Quantification of eggs on seagrass and macroalgae. During April 2002, different intertidal habitats were examined for herring eggs along the east coast of the island of Sylt: (1) extended Fucus vesiculosus beds associated with blue mussels Mytilus edulis located in the lower intertidal zone, (2) different seagrass beds in the upper intertidal zone, and (3) single F. vesiculosus aggregations associated with artificial bed groynes on the same tidal level as the seagrass beds. Egg abundance on algae and on seagrass were compared (egg numbers per unit plant biomass, and size of spawning zones). Six box corer samples $\left(100 \mathrm{~cm}^{2}\right)$ were taken from F. vesiculosus and 12 from Zostera noltii. Plant material was dried at $80^{\circ} \mathrm{C}$ for $48 \mathrm{~h}$ and combusted at $500^{\circ} \mathrm{C}$ for $14 \mathrm{~h}$ to estimate ash-free dry weight (AFDW). Egg numbers were estimated from the average weight of a single egg (0.001 g AFDW, SE $\pm 0.00004, \mathrm{n}=15$ ) extrapolated to the AFDW of spawn per $g$ AFDW plant biomass. The size of each spawning zone was measured and the total plant biomass was calculated for the whole spawning area. Seagrass beds with (Fig. 1, Site F) and without (Fig. 1, Site B) herring eggs were compared with respect to aboveground plant biomass and shoot density. Shoot density was measured using a metal frame of $25 \mathrm{~cm} \times 25 \mathrm{~cm}$ that was randomly placed on the seagrass canopy 3 times. The mean number of leaves per plant and mean length and width of leaves was measured from 120 randomly chosen plants.

Data analyses. Results of quantitative assessments are presented as arithmetic means with standard error $( \pm \mathrm{SE})$. Significance was tested using a 1-way ANOVA. Data sets were tested for homoscedasticity by Cochran's test and transformed using $\log (x+1)$ if necessary to fulfil the assumptions for ANOVA. Effects between single treatments of the spawning experiments on Belone belone were analysed using post hoc Tukey's honestly significant difference (HSD) test. Statistical significance was assumed if $\mathrm{p}<0.05$.

\section{RESULTS}

\section{Belone belone: Comparison of activity in different habitats}

With the exceptions of Sites A and E, all investigated Zostera noltii beds were visited by adult garfishes during the spawning season from May to July 2003. Activity of fishes was observed at Sites B, C and D (Fig. 1) in the Sylt-Rømø Bight as well as on the reference seagrass bed located in the separated Hörnum Deep tidal basin (Site F, Fig. 1). At Site B, sampling started with 219 'jumps' $30 \mathrm{~min}^{-1}$ recorded on 12 June, and repeated sampling showed almost identical results (206 'jumps' $30 \mathrm{~min}^{-1}$ ) at the end of the investigation period on 30 June. Therefore, no seasonal fluctuation in garfish activity could be observed during the sampling period. At Site B, garfishes showed significantly higher activity on tidal flats covered by $Z$. noltii (Fig. 2A) than on adjacent sand flats during the entire spawning season (ANOVA $\mathrm{p}=0.001$, $\mathrm{df}=1, F=12.81, \mathrm{n}=19$ ). In the $Z$. noltii bed, the mean number of counted 'jumps' 30 $\min ^{-1}(105 \pm 14)$ was consistently higher than mean number of 'jumps' $30 \mathrm{~min}^{-1}$ counted on sand flats $(24 \pm 6.09)$.

The mean abundance of Belone belone obtained by beach seine samples from May to July 2003 was 0.4 ind. $100 \mathrm{~m}^{-2}( \pm 0.15)$ over the Zostera noltii bed, whereas only 0.01 ind. $100 \mathrm{~m}^{-2}( \pm 0.01)$ were caught on adjacent sand flats (Fig. 2B). B. belone were significantly more abundant in seagrass beds (ANOVA, $\mathrm{p}=0.03, \mathrm{df}=1, F=5.61$ ) than on bare sands. Fishes caught on both sites had a mean length of $56.37 \mathrm{~cm}$ $( \pm 0.91, \mathrm{n}=15)$ and a mean fresh weight of $223 \mathrm{~g}$ $( \pm 9.0, \mathrm{n}=15)$.
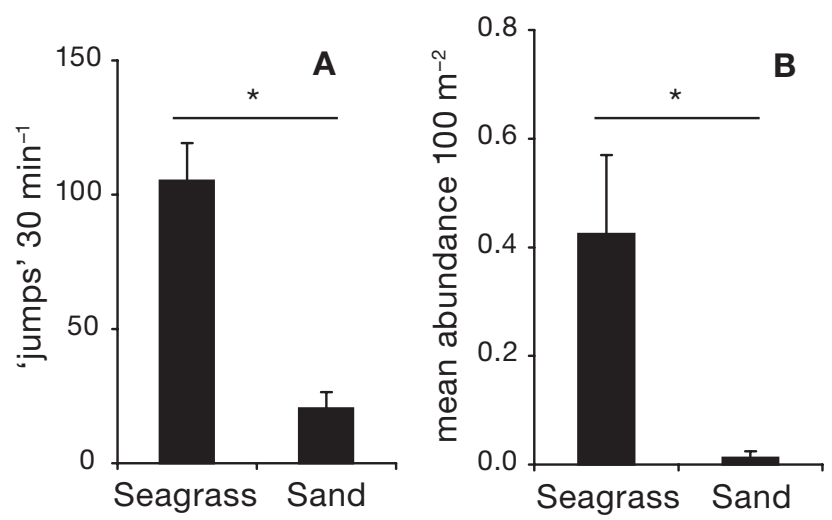

Fig. 2. Belone belone. (A) Mean activity $( \pm \mathrm{SE} ; \mathrm{n}=19)$ on vegetated (seagrass Zostera noltii) and non-vegetated (bare sand) tidal flats during the spawning season. (B) Mean abundance $( \pm \mathrm{SE})$ over $Z$. noltii beds $(\mathrm{n}=11)$ and bare sand flats $(n=8)$ pooled over the sampling period. ${ }^{\star} p<0.05$ 


\section{Belone belone: In situ spawning experiments}

From early June to late July, a mean density of $6( \pm 1)$ Belone belone eggs $\mathrm{m}^{-2}$ was found in the Zostera noltii control area. Outside the control areas, eggs were found attached to experimental Fucus vesiculosus and bast fibre units that were located within the seagrass bed.

Generally the number of Belone belone eggs pooled from all investigation units was significantly higher in the Zostera noltii bed than on adjacent bare sand flats (ANOVA, $\mathrm{p}<0.001, \mathrm{df}=1, F=36$ ) (Fig. 3). Within the seagrass bed, the mean egg number on artificial bast units did not differ significantly from those found in the seagrass control areas (Table 1, Tukey's test, $\mathrm{p}=0.46$ ). Significantly more eggs were found on both seagrass and bast units than on PVC mats covered with Fucus vesiculosus (Tukey's test seagrass, $\mathrm{p}<0.05$; Tukey's test bast, $\mathrm{p}<0.001$ ). In turn, experimental units covered with $F$. vesiculosus had significantly higher numbers of eggs when placed in the $Z$. noltii bed compared to those placed on bare sand (Tukey's test, $p<0.01$ ). On the non-vegetated sand flat, $F$. vesiculosus units (mean egg number $0.08 \pm 0.08$ ) and bast units (mean egg number $0.5 \pm 0.3$ ) did not show significant differences to the non-vegetated control areas, where no eggs were observed during the investigation period (Table 1).

Transplantation of green algae containing Belone belone eggs from the seagrass bed to unvegetated tidal flats showed that egg survival decreased when seagrass was absent (Fig. 4). On non-vegetated sand flats, ANOVA showed significant differences $(p<0.0001$, $\mathrm{df}=2, F=35.6$ ) between the original mean abundance of $B$. belone eggs on transplanted green algal units $(5.1 \pm 0.5, \mathrm{n}=10)$, total egg numbers recovered after $5 \mathrm{~d}$, and eggs recovered in a viable condition. The total number of eggs recovered $(3.3 \pm 0.5, \mathrm{n}=10)$ was significantly less than numbers initially transplanted (Tukey's test, $\mathrm{p}=0.01$ ). Based on total egg number recovered, a mean of only 0.2 eggs $( \pm 0.1, \mathrm{n}=10)$ were found to be optically intact. Thus, the number of eggs that survived was significantly lower than the total

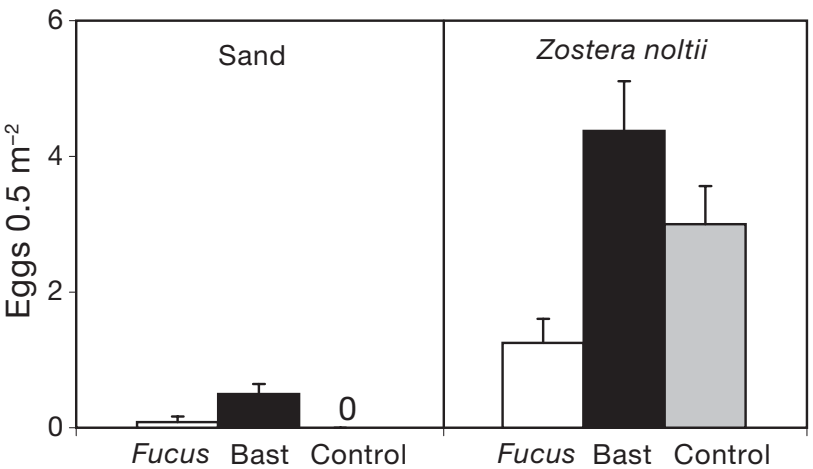

Fig. 3. Belone belone. Mean number $( \pm \mathrm{SE})$ of eggs on experimental units and untreated control areas offered as spawning substrate in vegetated and unvegetated tidal flats (for statistical effects see Table 1). Fucus = Fucus vesiculosus

number recovered on green algae situated on bare sand (Tukey's test, $\mathrm{p}=0.0001$ ). In the seagrass bed, ANOVA showed no significant effect $(\mathrm{p}=0.1, \mathrm{df}=2$, $F=2.5$ ) between mean egg number initially transplanted together with the algal clumps $(6.4 \pm 1.0$, $\mathrm{n}=10$ ), mean number of total eggs recovered after $5 \mathrm{~d}$ $(5.4 \pm 0.7, \mathrm{n}=9)$, and number of eggs found to be optically intact $(4.0 \pm 0.6, n=9)$. The total number of recovered eggs was not significantly less than initial egg abundance (Tukey's test, $\mathrm{p}=0.6$ ), and the number of vital eggs recovered did not differ significantly from the total number of eggs recovered after the experimental period (Tukey's test, $\mathrm{p}=0.08$ ).

\section{Clupea harengus: Quantification of eggs on seagrass and macroalgae}

In the intertidal area, Fucus vesiculosus as well as Zostera noltii were found to be used as substrate by spawning herring Clupea harengus. In April 2002, when the eggs were found, no adult $C$. harengus could be captured in the intertidal zone. Herring eggs were not homogeneously distributed within the seagrass beds but appeared to be concentrated in certain spawning zones. In the southern tidal basin, i.e. the

Table 1. Belone belone. Comparison of use of experimentally offered spawning substrates in Zostera noltii beds and on unvegetated sand flats (Tukey's post hoc test). ${ }^{* *} \mathrm{p}<0.01,{ }^{* * *} \mathrm{p}<0.001, \mathrm{~ns}=$ not significant

\begin{tabular}{|c|c|c|c|c|c|c|}
\hline \multirow{2}{*}{ Treatment } & \multicolumn{3}{|c|}{$\longrightarrow$ Sand - } & \multicolumn{3}{|c|}{$\longrightarrow$ Zostera noltii } \\
\hline & Fucus vesiculosus & Bast & Control & Fucus vesiculosus & Bast & Control \\
\hline Sand \& Fucus vesiculosus & & ns & ns & ** & $* * *$ & $* * *$ \\
\hline Sand \& bast & ns & & ns & ns & $* * *$ & $* * *$ \\
\hline Sand control & ns & ns & & $* * *$ & $* * *$ & $* * *$ \\
\hline Zostera noltii \& Fucus vesiculosus & ** & ns & $* *$ & & $* * *$ & $* *$ \\
\hline Zostera noltii \& bast & $* * *$ & $* * *$ & $* * *$ & $* * *$ & & ns \\
\hline Zostera noltii control & $* * *$ & $* * *$ & $* * *$ & ** & ns & \\
\hline
\end{tabular}




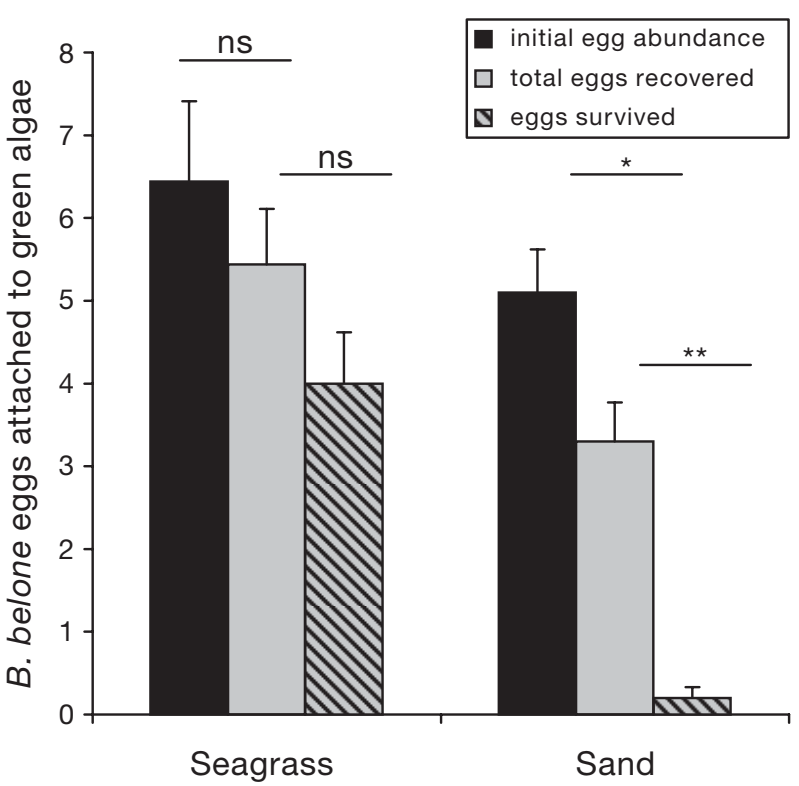

Fig. 4. Belone belone. Mean number $( \pm \mathrm{SE})$ of eggs originally attached to units of green algae (Enteromorpha spp.) that were transplanted to a Zostera noltii seagrass bed $(\mathrm{n}=9)$ and non-vegetated sand flat $(\mathrm{n}=10)$. Data are number of eggs initially found on transplanted algae, number recovered after a $5 \mathrm{~d}$ period, and number recovered in a vital condition. ${ }^{*} \mathrm{p}<0.05,{ }^{* *} \mathrm{p}<0.001, \mathrm{~ns}=$ non significant

Hörnum Deep (Fig. 1, Site F), a $190 \mathrm{~m}$ long and $9 \mathrm{~m}$ wide belt within the $Z$. noltii bed was identified as a spawning zone. The belt ran parallel to the high tide mark. In this belt the mean $Z$. noltii shoot density was $3088 \mathrm{~m}^{-2}$, with a mean biomass of $55 \mathrm{~g}( \pm 4.5)$ AFDW $\mathrm{m}^{-2}$. The $Z$. noltii plants had a mean leaf length of $8.4 \mathrm{~cm}( \pm 0.2, \mathrm{n}=120)$, a width of $0.95 \mathrm{~mm}( \pm 0.01$, $\mathrm{n}=120$ ), and a mean number of 2.5 leaves per plant $( \pm 0.07, \mathrm{n}=120)$. The mean number of eggs was 27 $( \pm 2.5, \mathrm{n}=120)$ per seagrass plant.

In the Sylt-Rømø Bight, plant biomass of Zostera noltii beds (Fig. 1, Site B) was only $9 \mathrm{~g}( \pm 1)$ AFDW m ${ }^{-2}$ during April 2002. No eggs could be observed attached to seagrass leaves here, but they were found on Fucus vesiculosus associated with bed groynes located in the upper intertidal zone; these spawning zones were limited to 2 patches with lengths of $3.5 \mathrm{~m}$ and $0.6 \mathrm{~m}$ and a width of $5.5 \mathrm{~m}$. Within both spawning zones algal biomass was $500 \mathrm{~g}( \pm 0.5)$ AFDW m${ }^{-2}$. The amount of herring eggs found in relation to plant biomass and spawning zone is given in Table 2. The number of herring eggs per $g$ AFDW plant biomass was more than 20 times higher in the seagrass spawning zone than in the F. vesiculosus spawning zone. This resulted in 2-fold higher egg numbers $\mathrm{m}^{-2}$ in the seagrass bed, even though plant biomass $\mathrm{m}^{-2}$ was much higher in the F. vesiculosus spawning zones on bed groynes.

\section{Gasterosteus aculeatus: Quantification of breeding fish}

In the period from late April to June, the threespined stickleback Gasterosteus aculeatus was found at a mean abundance of 3 ind. $100 \mathrm{~m}^{-2}( \pm 0.9, \mathrm{n}=7)$ on tidal flats covered by Zostera noltii, whereas no sticklebacks were caught on non-vegetated areas. The mean total length of captured individuals was $6.2 \mathrm{~cm}( \pm 0.09$, $\mathrm{n}=20)$ with a mean wet weight of $2.3 \mathrm{~g}( \pm 0.10, \mathrm{n}=20)$. Females with ripe ovaries had a mean length of $7.1 \mathrm{~cm}$ $( \pm 0.12, \mathrm{n}=20)$ and a mean wet weight of $3.5 \mathrm{~g}( \pm 0.16$, $\mathrm{n}=20$ ). A random sample of 99 female fishes showed that $54.6 \%$ were carrying spawn. A sample of 84 male sticklebacks showed that $44 \%$ exhibited breeding colours.

\section{DISCUSSION}

This study demonstrated a significant utilisation of Zostera noltii beds as spawning areas by migratory North Sea fishes. The results were rather unexpected in light of long periods of exposure and fluctuating environmental conditions - such as temperature and salinity - that predominate in the intertidal zone. The importance of intertidal $Z$. noltii beds might be increased by the absence of other suitable spawning substrates in the studied system, which is dominated by soft sediments. In contrast to Belone belone, eggs of

Table 2. Clupea harengus. Quantitative description of a spawning event in April 2002. Egg numbers in relation to plant biomass (pb) projected to dimensions of spawning zones (sz) found in the intertidal area

\begin{tabular}{|c|c|c|c|c|c|}
\hline $\begin{array}{l}\text { Intertidal spawning } \\
\text { area }\end{array}$ & $\begin{array}{l}\text { Dimension of } \\
\mathrm{sz}\left(\mathrm{m}^{2}\right)\end{array}$ & $\begin{array}{c}\mathrm{pb} \\
\left(\mathrm{g} A F D W \mathrm{~m}^{-2}\right)\end{array}$ & $\mathrm{kg}^{-1}$ AFDW pb & No. of eggs $\underset{\mathrm{m}^{-2}}{ }\left(\times 10^{3}\right)$ & $\mathrm{sz}^{-1}$ \\
\hline \multicolumn{6}{|l|}{ Fucus vesiculosus } \\
\hline Area 1 & 2.10 & 500 & 67 & 34 & 70 \\
\hline Area 2 & 19.25 & 500 & 67 & 34 & 655 \\
\hline \multicolumn{6}{|l|}{ Zostera noltii } \\
\hline Area 3 & 1653 & 55 & 1500 & 82.5 & 136400 \\
\hline
\end{tabular}


Clupea harengus were also found on Fucus vesiculosus when algae were located in the same tidal range as the seagrass beds. However, seagrass beds are considered to represent spawning grounds that are far more quantitatively effective than alternative structures in the intertidal zone.

Fish species found migrating to Zostera noltii beds for spawning were formerly described to spawn in subtidal $Z$. marina meadows, before these meadows disappeared during the 'wasting disease' (Wohlenberg 1935). Unfortunately, no information is available on the ecological functions of $Z$. noltii beds when they coexisted with subtidal $Z$. marina meadows in the Wadden Sea. Whether intertidal seagrass beds are a residual spawning area for species that formerly reproduced in subtidal seagrass areas or whether spawning in intertidal canopies provides a certain advantage for the development of eggs could not yet be clarified. However, embryonic stages of Belone belone are able to tolerate fluctuations in temperature and salinity (Rosenthal \& Fonds 1973, von Westernhagen 1974, von Westernhagen et al. 1975). Furthermore, von Westernhagen (1974) found that eggs developed much faster at a temperature of $24^{\circ} \mathrm{C}$ than at $18^{\circ} \mathrm{C}$. In fact, this temperature difference represented approximately that between intertidal and shallow subtidal areas during the investigation period. Thus, it is assumed that environmental conditions in the intertidal zone promote embryonic development, which points to a beneficial role that $Z$. noltii beds may play as spawning grounds. Since tidal flats are exposed to air extensively during the tidal cycle, the layer of residual water retained by the seagrass canopy during low tide is most probably conducive to the survival of eggs in the intertidal zone. Eggs attached to a different substrate, such as green algae, might be protected against desiccation by this canopy water layer during low tide, whereas on bare sediments egg mortality is comparatively high.

The activity of Belone belone observed in different seagrass sites along the east coast of the island of Sylt indicated that fishes enter the intertidal zone with the rising tide and migrate to Zostera noltii meadows located close to the main tidal gullies. $B$. belone activity was also observed at the reference site in the southern Hörnum Deep tidal basin of the island. Because a causeway completely separates both tidal basins, it is assumed that migration of $B$. belone to $Z$. noltii beds during the spawning season is not restricted to the Sylt-Rømø Bight, but might also occur in other Wadden Sea areas. The JUMP method was not a suitable method to measure abundance of $B$. belone, because fishes were able to dive underneath the rope and repeated jumps by the same individual were thus possible. However, a direct comparison of garfish activity in adjacent vegetated and non-vegetated intertidal habitats at a particular tidal level over the whole investigation period indicated that tidal migration of adult fishes is especially directed to intertidal $Z$. noltii beds. The results from the spawning experiment strongly support the hypothesis of a $B$. belone spawning migration distinctly directed to the seagrass habitat, because eggs were attached to any suitable structure as long as it was located inside the $Z$. noltii bed. Since significantly fewer eggs were found attached to Fucus vesiculosus compared to artificial bast structures and seagrass control areas, brown algae such as F. vesiculosus are not considered to represent relevant spawning substrate alternatives to seagrass.

Clupea harengus eggs were observed in the intertidal zone during the period from April to May, when (aboveground) seagrass density is usually low (Schanz \& Asmus 2003). In spring 2002, no eggs could be found in seagrass canopies with low plant density in the Sylt-Rømø Bight (Fig. 1, Site B): they were instead observed on single patches of Fucus vesiculosus. However, a mismatch between spawning season and seagrass availability, and a certain threshold value with respect to shoot density, might be responsible for the discrepancy in utilisation of seagrass canopies between the Sylt-Rømø Bight and the Hörnum Deep tidal basin for spawning. The relationship between egg number and $g$ AFDW plant biomass indicated that at a shoot density $\geq 30000$, or $55 \mathrm{~g}$ AFDW plant biomass $\mathrm{m}^{-2}$, Zostera noltii beds are quantitatively far more important spawning areas than patches of macro algae.

Clupea harengus eggs found in the intertidal zone of the island of Sylt are not considered to be quantitatively important for the total North Sea herring stock. However, the 'adopted-migrant' hypothesis, which assumes that juvenile fishes learn to find suitable spawning grounds by following the adults (Corten 1993, McQuinn 1997, Corten 2001), might increase the significance of these local spots for population diversity of herring and might point to a possible recovery of eastern North Sea herring stocks (C. Zimmermann pers. comm.). It is documented that in the absence of subtidal vegetation, herring started to spawn on bare sediments in the Baltic Sea, which led to increased embryonic mortality (Raid 1990). As a result, it could be assumed that the reproductive success of herring is enhanced by the presence of marine macrophytes such as seagrasses.

During this study, single camouflaged nests of Gasterosteus aculeatus were found in the investigation area but could not be quantified because of their effective camouflage. In general, G. aculeatus is known to leave the marine environment in spring to migrate to brackish and freshwater areas for spawning (Zijlstra 1978). Since high percentages of female sticklebacks with ripe ovaries and male individuals with breeding 
colours were found in $Z$. noltii beds, we assumed that G. aculeatus additionally reproduces in polyhaline Wadden Sea waters. Gasterosteus aculeatus is a typical example of a fish species that exhibits intensive parental care and territorial behaviour (Tinbergen 1951, Reebs et al. 1984, Lachance \& FitzGerald 1992). In the intertidal area, we consider seagrass beds to be suitable spawning grounds for small, breeding species such as the stickleback, as the residual canopy water layer allows parental care without tidal migration.

\section{CONCLUSION}

Although Zostera noltii beds in the Wadden Sea are only temporarily available during the tidal cycle, common fish species that embark on different spawning strategies use them as spawning grounds in the intertidal area. A lack of alternative spawning structures may intensify the importance of $Z$. noltii beds in the Wadden Sea. However, it is proposed that intertidal seagrass plants are directly frequented for spawning, and that they support embryonic development of Belone belone, Clupea harengus and Gasterosteus aculeatus by providing a suitable environment over the whole tidal cycle. Since intertidal seagrass stocks are considered to represent a reproduction area for fishes in the northern Wadden Sea, continuous seagrass losses might affect North Sea fish populations, trophic structures and biodiversity.

Acknowledgements. Many thanks to A. Zipperle, P. Götz and A. Schanz for all their assistance during fieldwork. We gratefully acknowledge R. Asmus, D. Baird and 3 anonymous referees, who improved the manuscript with valuable comments and helped to correct the English. The project was carried out under the MARBEF Network of Excellence 'marine biodiversity and ecosystem functioning', which is funded by the European Community's Sixth Framework Programme (contract no. GOCE-CT-2003-505446). This publication is contribution number MPS-05016 of MARBEF.

\section{LITERATURE CITED}

Asmus H (1987) Secondary production of an intertidal mussel bed community related to its storage and turnover compartments. Mar Ecol Prog Ser 39:251-266

Beck MW, Heck KL Jr, Able KW, Childers DL and 9 others (2001) The identification, conservation and management of estuarine and marine nurseries for fish and invertebrates. BioScience 51:633-641

Boström C, Bonsdorff E (2000) Zoobenthic community establishment and habitat complexity - the importance of seagrass shoot-density, morphology and physical disturbance for faunal recruitment. Mar Ecol Prog Ser 205:123-138

Buschbaum C, Saier B (2001) Growth of the mussel Mytilus edulis L. in the Wadden Sea affected by tidal emergence and barnacle epibionts. J Sea Res 45:27-36
Christensen V, Guenette S, Heymans JJ, Walters CJ, Watson R, Zeller D, Pauly D (2003) Hundred-year decline of North Atlantic predatory fishes. Fish Fisheries 4:1-24

Connolly RM (1994) A comparison of fish assemblages from seagrass and unvegetated areas of a southern Australian Estuary. Aust J Mar Freshw Res 45:1033-1044

Corten A (1993) Learning processes in herring migrations. ICES CM 1993/H:18

Corten A (2001) The role of 'conservatism' in herring migrations. Rev Fish Biol Fish 11:339-361

den Hartog C, Polderman PJG (1975) Changes in the seagrass population in the Dutch Waddenzee. Aquat Bot 1:141-147

Dorman JA (1991) Investigations into the biology of the garfish, Belone belone (L.), in Swedish waters. J Fish Biol 39:59-69

Duncker G, Ehrenbaum E, Kyle HM, Mohr EW, Schnakenbeck W (1929) In: Grimpe G (ed) Die Tierwelt der Nordund Ostsee. Akademische Verlagsgesellschaft, Leipzig

Edgar GJ, Shaw C (1995) The production and trophic ecology of shallow-water fish assemblages in southern Australia. I. Species richness, size structure and production of fishes in Western Port, Victoria. J Exp Mar Biol Ecol 194:53-81

Elliott M (2003) Biological pollutants and biological pollution-an increasing cause for concern. Mar Pollut Bull $46: 275-280$

Fonseca MS, Calahan JA (1992) Preliminary evaluation of wave attenuation by four species of seagrass. Estuar Coast Shelf Sci 35:565-576

Fonseca MS, Fisher JS, Ziemann JC, Thayer GW (1982) Influence of the seagrass Zostera marina L. on current flow. Estuar Coast Shelf Sci 15:35-364

Gambi MC, Nowell AMR, Jumars PA (1990) Flume observations on flow dynamics in Zostera marina (eelgrass) beds. Mar Ecol Prog Ser 61:159-169

Gätje C, Reise K (1998) Ökosystem Wattenmeer, Austausch-, Transport- und Stoffumwandlungsprozesse. SpringerVerlag, Berlin

Gemp KP, Bryzova LB (1968) The vegetation on spawning grounds of herring. Tr Kapros Niorch 2:32-33

Goscheva TD (1970) Spawning places of the White Sea herring. Materialy rybochzjă̌stvennych issljedovaniı̌ Severnogo basseǐna. Wyl 13:76-83

Grizzle RE, Short FT, Newell CR, Hoven H, Kindblom L (1996) Hydrodynamically induced synchronous waving of seagrass: 'monami' and its possible effects on larval mussel settlement. J Exp Mar Biol Ecol 206:165-177

Groehsler T, Zimmermann C (2001) The situation of fish stocks in the NE Atlantic and in North and Baltic Sea: assessment of the International Council for the Exploration of the Sea in spring 2001. Inf Fischwirtsch Fischereiforsch 48:95-113

Hindell SJ, Jenkins GP, Keough MJ (2001) Spatial and temporal variability in the effects of fish predation on macrofauna in relation to habitat complexity and cage effects. Mar Ecol Prog Ser 224:231-250

Hoshikawa H, Tajima K, Kawai T, Ohtsuki T (2001) Spawning bed selection by Pacific herring (Clupea pallasii) at Atsuta, Hokkaido, Japan. Lowell Wakefield Fish Symp Ser 18: 199-226

Hughes JE, Deegan LA, Wyda JC, Weaver MJ, Wright A (2002) The effects of eelgrass habitat loss on estuarine fish communities of southern New England. Estuaries 25:235-249

Jennings S, Kaiser MJ (1998) The effects of fishing on marine ecosystems. Adv Mar Biol 34:201-352

Koch EW, Gust G (1999) Water flow in tide- and wavedominated beds of seagrass Thalassia testudinum. Mar Ecol Prog Ser 184:63-72

Lachance S, FitzGerald GJ (1992) Parental care tactics of three- 
spined sticklebacks living in a harsh environment. Behav Ecol 3:360-366

Lakke M (1985) Forurensningene I Nordsjoeen (Pollution in the North Sea). Norsk Fiskeoppdrett 10:16-18

Mattila J (1992) The effect of habitat complexity on predation efficiency of perch (Perca fluviatilis (L.) and ruffe Gymnocephalus cernuus (L.). J Exp Mar Biol Ecol 15:55-67

McQuinn IH (1997) Metapopulations and the Atlantic herring. Rev Fish Biol Fish 7:297-329

Messieh S, Pottle R, Macpherson P, Hurlbut T (1985) Spawning and exploitation of Atlantic herring (Clupea harengus) at Escuminac in the southwestern Gulf of St. Lawrence, spring 1983. J Northwest Atl Fish Sci 6:125-133

Michaelis H (1987) Bestandsaufnahme des eulitoralen Makrobenthos im Jadebusen in Verbindung mit einer LuftbildAnalyse. Forschungsstelle Küste 38:13-97

Minello TJ, Able KW, Weinstein MP, Hays C (2003) Salt marshes as nurseries for nekton: testing hypotheses on density, growth and survival through meta-analysis. Mar Ecol Prog Ser 246:39-59

Moksnes PO (2002) The relative importance of habitat-specific settlement, predation and juvenile dispersal for distribution and abundance of young juvenile shore crabs Carcinus maenas L. J Exp Mar Biol Ecol 271:41-73

Nelson WG, Bonsdorff E (1990) Fish predation and habitat complexity: are complexity thresholds real? J Exp Mar Biol Ecol 141:183-194

Orth RJ, Heck KL Jr, van Montfrans J (1984) Faunal communities in seagrass beds: a review of the influence of plant and animal structure and prey characteristics on predator prey relationships. Estuaries 7:339-350

Philippart CJM (1998) Long-term impact of bottom fisheries on several by-catch species of demersal fish and benthic invertebrates in the south-eastern North Sea. ICES J Mar Sci 55:342-352

Raid T (1990) On herring reproduction in the Northeastern Baltic. ICES CM, Copenhagen

Reebs SG, Whoriskey FG Jr, FitzGerald GJ (1984) Diel patterns of fanning activity, egg respiration, and the nocturnal behavior of male three-spined sticklebacks, Gasterosteus aculeatus L. (F. trachurus). Can J Zool 62:329-334

Reise K (2003) Grüner Wechsel im Wattenmeer: Weniger Seegraswiesen und das Aufkommen der Grünalgenmatten. In: Lozán JL, Rachor E, Reise K, Sündermann J, von Westernhagen $\mathrm{H}$ (eds) Warnsignale aus der Nordsee \& Wattenmeer - eine aktuelle Umweltbilanz. Wissenschaftliche Auswertungen/GEO, Hamburg, p 196-200

Rosenthal H, Fonds M (1973) Biological observations during rearing experiments with the garfish Belone belone. Mar Biol 21:203-218

Editorial responsibility: Otto Kinne (Editor-in-Chief), Oldendorf/Luhe, Germany
Rowland WJ, Grindle N, Mclaren RD, Granquist R (2002) Male preference of a subtle posture cue that signals spawning readiness in female sticklebacks. Anim Behav 63:743-748

Schanz A, Asmus H (2003) Impact of hydrodynamics on development and morphology of intertidal seagrasses in the Wadden Sea. Mar Ecol Prog Ser 261:123-134

Schanz A, Polte P, Asmus H (2002) Cascading effects of hydrodynamics on an epiphyte-grazer system in intertidal seagrass beds of the Wadden Sea. Mar Biol 141: 287-297

Scott LC, Boland JW, Edyvane KS, Jones GK (2000) Development of a seagrass-fish habitat model. I: A seagrass residency index for economically important species. Environmetrics 11:541-552

Short FT, Short CA (1984) The seagrass filter: purification of estuarine and coastal waters. In: Kennedy VS (ed) The estuary as a filter. Academic Press, New York, p 269-322

Thrush SF, Hewitt JE, Funnell GA, Cummings VJ, Ellis J, Schultz D, Talley D, Norkko A (2001) Fishing disturbance and marine biodiversity: role of habitat structure in simple soft-sediment systems. Mar Ecol Prog Ser 221: 255-264

Tinbergen N (1951) Study of instinct. Clarendon Press, Oxford

Vanderklift MA, Jacoby CA (2003) Patterns in fish assemblages 25 years after major seagrass loss. Mar Ecol Prog Ser 247:225-235

von Westernhagen $H$ (1974) Incubation of garpike eggs (Belone belone, L.) under controlled temperature and salinity conditions. J Mar Biol Assoc UK 54:625-634

von Westernhagen H, Dethlefsen V, Rosenthal H (1975) Combined effects of cadmium and salinity on development and survival of garpike eggs. Helgoländer Wiss Meeresunters $27: 268-282$

Wechov WN (1987) The status of Zostera in spawning grounds of the Kandalakscha Bay in the White Sea. West MGU Ser Biol 1:24-29

Wohlenberg E (1935) Beobachtungen über das Seegras Zostera marina L. und seine Erkrankung im nordfriesischen Wattenmeer. Beitr Heimatforsch Schleswig-Holstein 11:1-19

Wyda JC, Deegan LA, Hughes JE, Weaver MJ (2002) The response of fishes to submerged aquatic vegetation complexity in two ecoregions of the Mid-Atlantic Bight: Buzzards Bay and Chesapeake Bay. Estuaries 25:86-100

Zijlstra JJ (1978) The function of the Wadden Sea for the members of its fish-fauna. In: Dankers N, Wolff WJ, Zijlstra JJ (eds) Fishes and fisheries of the Wadden Sea. Final report of the section 'Fishes and fisheries' of the Wadden Sea Working Group, Leiden, p 20-25

Submitted: August 23, 2004; Accepted: November 23, 2005 Proofs received from author(s): March 20, 2006 